\title{
Development of Monoclonal Antibodies: The Dawn of mAb Rule
}

\author{
Jonathan D. Kaunitz ${ }^{1,2}$
}

Published online: 8 February 2017

(C) Springer Science+Business Media New York (Outside the USA) 2017

Underlying most major therapeutic advances are fundamental discoveries that shake scientific discourse to its core, usually generating Nobel prizes and entirely new fields of study. In this eighth installment of the series entitled "Paradigm Shifts in Perspective," Drs. Sofia and Rubin highlight the considerable impact that therapeutic monoclonal antibodies (mAbs) have made on gastrointestinal practice.

The history of antibody development can be traced back to the eighteenth century, with the discovery that fluid obtained from a smallpox pustule when injected into a recipient provided immunity from acquiring the disease. Edward Jenner, who famously used fluid from cowpox pustules to immunize against smallpox, advanced these studies. The discovery of antibodies can be traced to von Behring and Kitasato, who in 1890 published the landmark finding that transfer of serum from animals that had been immunized to diphtheria to animals infected with diphtheria altered the course of the disease. Going forward to the twentieth century, the pioneering work of Paul Ehrlich and Emil Fischer regarding antibody configuration was remarkably predictive of the current understanding of antibody structure. The Nobel Prize was awarded in 1972 to Gerald Edelman and Rodney Porter for their contributions to the understanding of the chemical structure of antibodies.

Jonathan D. Kaunitz

jake@ucla.edu

1 West Los Angeles VA Medical Center, Bldg. 114/217E, 11301 Wilshire Boulevard, Los Angeles, CA 90073, USA

2 UCLA School of Medicine Los Angeles, Los Angeles, CA 90073, USA
The background to the concept of monoclonal antibodies dates from the 1930s, when McMaster and Hudack isolated agglutinins from lymph nodes [1]. Further work by Harris et al. [2] identified lymphocytes as the source of antibody production. In 1942, Bjørneboe and Gormsen, correlated plasma cell proliferation with antibody production, concluding that plasma cells were the primary source of antibody production [3]. In the same year, Moore, Kabat, and Gutman published a groundbreaking study on the characteristics of Bence-Jones proteins characteristic of myeloma [4]. Many studies of the 1940s-1960s focused on physical descriptions of these proteins with suggestions of their monoclonal origin [5, 6], with the first confirmation of their origin from a single plasma cell clone published by Awdeh et al. [7] from the National Institute for Medical Research in London (NIMR).

Antibodies were traditionally made by immunizing experimental animals with an antigen with subsequent purification of the serum in order to isolate the antibody fraction. In 1970, Brigitte Askonas et al. [8] from the NIMR described a technique wherein they isolated a single plasma cell clone that generated a homogeneous antibody, propagated by repeated passage of spleen cells into irradiated syngeneic mice, apparently the first description of laboratory monoclonal antibody production. In 1975, Köhler and Milstein published a revolutionary paper in which they fused an antibody-producing plasma cell with a myeloma cell, the latter, which, due to its transformed nature, could be propagated indefinitely in culture. The advantage of this technique is that it enabled the production of limitless amounts of antibodies in vitro [9]. Thus, the "hybridoma" was born with its promise to produce unlimited quantities of monospecific antibodies, an innovation that changed the field of immunology forever, recognized by the awarding of the Nobel Prize in 1984 to 
Köhler and Milstein. Since 1975, refinements of the technique have enabled the production of engineered, fully humanized antibodies suitable for the therapy of humans [10]. Monoclonal antibodies have been in clinical development, with the anti-rejection monoclonal antibody muromonab-CD3 the first monoclonal antibody to be approved by the US Food and Drug Administration (FDA) for clinical use in 1985 [11]. Since then, many have followed, with the first monoclonal antibody approved for the therapy of inflammatory bowel disease (IBD), infliximab, approved in 1988 [12].

In the accompanying article, Drs. Sofia and Rubin provide an in-depth overview of monoclonal antibody-based therapeutics for IBD and other digestive diseases, treatments that have revolutionized the therapy of complex and difficult-to-treat diseases.

\section{References}

1. McMaster PD, Hudack SS. The formation of agglutinins within lymph nodes. J Exp Med. 1935;61:783-805.

2. Harris TN, Grimm E, Mertens E, Ehrich WE. The role of the lymphocyte in antibody formation. J Exp Med. 1945;81:73-83.
3. Bjørneboe M, Gormsen H. Experimental studies on the role of plasma cells as antibody producers. 1942. APMIS. 2007;115: 440-483.

4. Moore DH, Kabat EA, Gutman AB. Bence-Jones proteinemia in multiple myeloma. J Clin Invest. 1943;22:67-75.

5. Osserman EF, Lawlor DP. Abnormal serum and urine proteins in thirty five cases of multiple myeloma, as studied by filter paper electrophoresis. Am J Med. 1955;18:462-476.

6. Waldenstrom J. Monoclonal and polyclonal gammopathies and the biological system of gamma globulins. Prog Allergy. 1962;6: 320-348.

7. Awdeh ZL, Askonas BA, Williamson AR. The homogeneousgamma-G-immunoglobulin produced by mouse plasmacytoma 5563 and its subsequent heterogeneity in serum. Biochem J. 1967; 102:548-553.

8. Askonas BA, Williamson AR, Wright BE. Selection of a single antibody-forming cell clone and its propagation in syngeneic mice. Proc Natl Acad Sci USA. 1970;67:1398-1403.

9. Köhler G, Milstein C. Continuous cultures of fused cells secreting antibody of predefined specificity. Nature. 1975;256:495-497.

10. Liu JK. The history of monoclonal antibody development-progress, remaining challenges and future innovations. Ann Med Surg (Lond). 2014;3:113-116.

11. Smith SL. Ten years of orthoclone OKT3 (muromonab-CD3): a review. J Transpl Coord. 1996;6:109-119.

12. Danese S, Vuitton L, Peyrin-Biroulet L. Biologic agents for IBD: practical insights. Nat Rev Gastroenterol Hepatol. 2015;12: 537-545. 